\title{
Indonesian in Service Teacher's Production of Directive Speech Acts and Students' Responses
}

DOI: https://doi.org/10.47175/rielsj.v1i3.158

\begin{abstract}
| Alfi Nur Azizah ${ }^{1, *}$ | Suparno² | Slamet Supriyadi ${ }^{3}$ |
${ }^{1}$ Magister student of English

Education, Department of

English Education, Sebelas

Maret University, Surakarta, Indonesia

2,3 Lecturer at Graduate

Program of English Education, Department of English

Education, Sebelas Maret

University, Surakarta, Indonesia

*alfinurazizahalfi@gmail.com

ABSTRACT

Teacher uses language as a medium of communication to teach, guide and instruct students in the classroom. This study aims to investigate the English teacher's directives and the students' responses to these directives. This study participants were an English teacher of a junior high school in Indonesia who teaches an eighth-grade class and her students who were chosen purposively. This qualitative case study was collected through observation, and interviews and were then analyzed by following Miles' interactive cyclical model. The results revealed that the teacher mostly produced directive speech acts types of commands and requests rather than suggestions. Commands have been the most commonly used type of directives since the teacher plays a control in the classroom because it is more understandable and familiar for the students. Hence, the students' responses varied, and depended on their response strategies and each personal reason. KEYWORDS

Directive Speech Acts; In Service Teacher; Pragmatics; Students' Responses
\end{abstract}

\section{INTRODUCTION}

Language is a means of communication that is essential to human beings. Human beings need a language to interact with each other and language is part of daily human life. According to Seken (2015), language is a medium of communication. It plays a role in numerous problems in today's world and that such issues cannot be overcome without knowing the essence of the language and without having insight into the language. As the primary means of communication, language is used to directly express feelings, perceptions, ideas, expectations, and emotions. The concept of language allows learners to communicate with a range of speakers in various contexts (Hussein, Albakri, \& Seng, 2019). Thus, language is capable of expressing a sense of action known as speech acts. The term of speech acts was firstly introduced by J. L. Austin, a professor at Harvard University, in his book How to do Thing with Word (1962). Austin says speech acts is an act that happens when you say something. It describes speech functions directly as an activity done by saying something. Many experts agree with the term speech acts as actions that are performed via utterances (Yule, 1996; Cutting, 2002). Speech acts theory generally explains utterances as having three dimensions: locutionary, illocutionary, and perlocutionary acts. Those three major dimensions of speech acts have particular meaning. The first, locutionary acts, underlines on the meaning of utterances without an intent to affect the hearer by performing an act of saying something. The second, is Illocutionary acts, which is the act of doing something and the functions of illocutionary acts are to say or give information and do something. The last is perlocutionary acts, the acts of affecting someone. In perlocutionary acts, there is an influence because the speaker tries to influence the listeners to do what he 
or she wants him or her to do. People in conversations use speech acts to deliver messages or thoughts.

According to Kreidler (2013), there are three types of directive speech acts, namely commands, requests, and suggestions. Each type has several different points over various meanings. The first types of directive speech act are commands. Commands refer to an utterance uttered by the speaker to get someone to do something based on what the speaker wants. Commands refer to an utterance spoken by the speaker to get someone to do something based on what the speaker wants. Commands can be delivered with varying explicitness levels (a charge, direct, order, tell, and demand), imperative sentences, and contain predicates as require and permit. The second, is requests types. Requests refer to an expression of what the speaker wants the addressee to do or refrain from doing. In taking request, the speaker cannot control the action of the addressee. The last type is suggestions that refer to the speaker's utterances to other persons to give his opinions as to what the hearers should or should not do. Pragmatics is a branch of linguistics that is related to meaning in context. The speaker and hearer must have pragmatic language skills to build relationships and communication skills in a range of contexts. All of the utterances that are used as a means of classroom communication refer to classroom speech acts.

The classroom speech acts are a significant concern for the teacher since it can contain information about the teacher's teaching behaviors that he frequently uses to communicate with the students. Interaction between teacher and students in the teaching and learning process is considered an essential aspect of successful learning. Teacher will create several utterances to explain the teaching materials through his speech as he interacts with his students. Hence, classroom speech acts discover verbal interaction quality (Merdana, Seken, \& Putra, 2013). In simple words, the use of speech acts in the classroom contributes to both teacher and students' social interaction. As Wajdi (in Andewi \& Waziana, 2019) said, teachers' speech acts are enormously important for the organization of the classroom and for the student acquisition process. Zulianti (2018) reported on her research that the use of speech acts in the school has a positive impact in which can boost students' motivation and the classroom atmosphere; thus, it develops a healthy relationship between teacher and students in learning and teaching process. Besides, classroom interaction involves students' language development and it is influenced by the use of various language functions in the classroom (Consolo, 2006).

Moreover, Hussein et al., (2020) stated that an English learner expected to be a successful language student might not communicate with the target language learners. They argued that English learners need to understand and have communicative competence, which involves both language competence and pragmatic competence for accomplishing communication between various nationalities in multiple areas. In sum, teacher-students relationship during teaching and learning is crucial in building effective communication habits. It is hoped that students will have great communication competence that can be implemented in the broader context.

In the classroom environment, teachers are supposed to take many roles; for example, a teacher can be a controller, director, facilitator, resource giving the materials, and feedback for the student's work (Brown, 2001). Teacher's role has changed massively from being an educator to become a constructor, facilitator, coach, and designer of learning environments (Amin, 2016). Besides, learning is the goal of teaching that fundamentally transfers knowledge and information from teachers to students. In providing more information, the teacher uses language to interact with the students to enlighten, advise, and give instruction to them. Huang (2010) proposed that EFL teachers create classroom situations that encourage students to produce oral language by introducing them to communication 
strategies. On the other hand, it would give benefit to students' communication fluency and skills. He concluded that EFL teachers would find more efficient methods to instruct students in productive communication strategies by empowering them to employ skillful strategies for future communication.

Realizing the importance of teacher's role, Funsho et. al (in Ezenekwe \& U, 2019) argue a great teacher can be seen as one who by his knowledge, character, and everyday life, leaves the most significant effect on the intellectual and moral character of his students. In other words, teacher reflects on a role model who will be imitated by students. Consequently, the teacher's role ultimately provides learners with skills and knowledge that the students can apply concisely to their functioning as adults to manage their lives, jobs, and involvement in social decision-making processes (Biggs \& Tang, 2011).

The research on directive speech acts, has been done by especially analyzing directive speech acts in films, political discourse, dialogic da'wah and novels. Unfortunately, the classroom context is still limited to revolve around the structure and types of directive speech act used by teacher to student and student to student.

Empirical researches of speech acts have explored spoken or written language in various communication contexts, including teaching (Azizah, Suparno, \& Tarjana, 2019; Basra \& Thoyyibah, 2017; Merdana et al., 2013; Zulianti, 2018) and a range of speech acts, including asking (Andewi \& Waziana, 2019; Isnawati, Anam, \& Diana, 2014), command (Patmo, 2017; Susanto, 2017), request (Azwan, 2018; Jabber \& Jinquan, 2013; Taguchi, 2006) and suggestion (Kamlasi, 2017; Wulansari \& Suhartini, 2015). These speech act studies discussed several study focuses, including the directive speech act variations and expressions (Haryanto \& Mubarok, 2018; Sulistyani, 2018; Suparno, 2013), directive function (Fatma, Prayitno, Jamaludin, Jha, \& Badri, 2019; Fatma, Sumarlam, \& Suwandi, 2018; Maskuri, Tarjana, Djatmika, \& Purnanto, 2019; Rasmodjo, 2016; Zulianti, 2018) and the differences contexts in the use of directives (Bijad Alharbi, 2018; Prasetyo \& Mulyani, 2018; Stevanovic \& Kuusisto, 2019).

As the students' strategies in replaying teachers utterances, they did various reactions such as gaze, body postures, gestures and other strategies such as asking for clarification strategy, no-response strategy (silent), excuse strategy, and asking for repetition (Bezemer, 2008; Dörnyei \& Scott, 1997; Lui, Bartosiak, Piccoli, \& Sadhya, 2018; Sumilia, Puspita, \& Elfrida, 2019; Wensi, Puspita, \& Afriazi, 2018).

To overcome these gaps, the present study concerned on teacher's variety in producing directive speech act in the classroom context and the students' behavior during the teaching learning process. Therefore, this study intends to explore teacher directive utterances and the students' responses to these directives. This study aims to investigate teacher directive utterances by classifying them into directive types then to describe the frequencies of each word and how the students in responding to those directives.

\section{RESEARCH METHODS}

The design of this study was a qualitative case study chosen to investigate a phenomenon in its real-life. Creswell (2007) stated that case study research is a qualitative approach in which the investigator explores a case or cases over time, through detailed, in-depth data collection involving multiple sources of information and reports a case description and case-based themes. This design was chosen because it aimed to investigate the teacher's directives and the student's response to these directives during the learning process in one of State Junior High School in Yogyakarta. The researcher observed the teacher's linguistic forms and the students' strategies in responding to their teacher's directive utterances. 
An eighth-grade English teacher and four students; two were boys, and two girls were purposively selected. The teacher is chosen because she was experienced more than fifteen years in teaching English for lower secondary students. She also has multilingual competence in Javanese, Indonesian, and English. Thus, she can communicate well with her students both in the local language and target language. It develops further interaction between the teacher and the students to furnish the data for this research. Simultaneously, the students are selected based on their English proficiency from their previous English marks because they can provide relevant information about how they respond to the teacher's directive utterances in their classes.

The data were obtained mainly through observation, and interviews. In doing observation, the researcher acts as a nonparticipant observer who cannot evaluate a teacher's lesson. In the observation process, the researcher takes note of what is happening in the classroom and uses a video camera to capture teaching and learning process. Henceforth, the data were sentences uttered by the teacher tapped by audio and video recorder to record teacher's instructions during English class activities.

In this study, the interviews were conducted to obtain more detailed information that cannot be reached in the observation process and get further information on how students interpret the teacher's directive. The interviews were highlighted to the four students involved in this study. It was undertaken in Indonesian, and the excerpts have been translated into English. During the interview process, the researcher operates an audio recorder to collect all the information given by students to assist the researcher in the ease of data transcriptions and to have an authentic record of the conversation.

The collected data were analyzed using the interactional model of Miles, Huberman, \& Saldana (2014), consisting of three stages: data condensation, data display, and drawing or verifying conclusion. Those data are collected through observation and interviews. Then they are transformed into the data condensation stage by transcribing the teacher's utterances occurring in the classroom interaction and writing interview transcripts, coding, and generating categories based on the problem statement. The data were classified and categorized based on specified characteristics. Then, they are displayed in a word description and obtained drawing and verifying conclusions as a result.

\section{RESULTS AND DISCUSSION}

There were data obtained from observation and interviews in identifying the teacher's directives and the students' responses. Based on the data collected, several findings were discovered based on the data gathered to answer the research questions.

\section{Teacher's linguistics forms of directives}

In the teaching and learning process, the teacher creates the directives to get the students to do things as the teacher wants. According to Searle (1969), directives are common speech acts in classroom activities. It happens because teacher always asks students to do something in the classroom. Hence, as cited Ivana Swastiana et al., (2020), the teacher's directive has shown that it has played its role in controlling the classroom education system, offering guidance and learning to students, and instructing and assessing students.

Directive speech acts are divided into three forms: commands, requests, and suggestions (Kreidler, 2013). Furthermore, three structural modes of expressing directive speech acts; declarative, interrogative, and imperative (Yule, 1996). The first mode is declarative, which is commonly used to make a statement. A declarative style implies a clear explanation of the desire or wishes expressed by the speaker. The second structural mode is the interrogative. The interrogative is frequently used to make a question and to soften the utterance. It may 
either use modal (can, may, must, shall, will, could, would, etc.) or non-modal. The last mode is imperative to give a command and state polite request by adding the word please (Lado, 1986).

The directive speech acts identified into three categories: command, request, and suggestion. In the classroom teacher and students talked about various activities related to the teaching and learning process. In term of the frequency of occurrence, the type of directives that often occurred in the classroom can be drawn as follows:

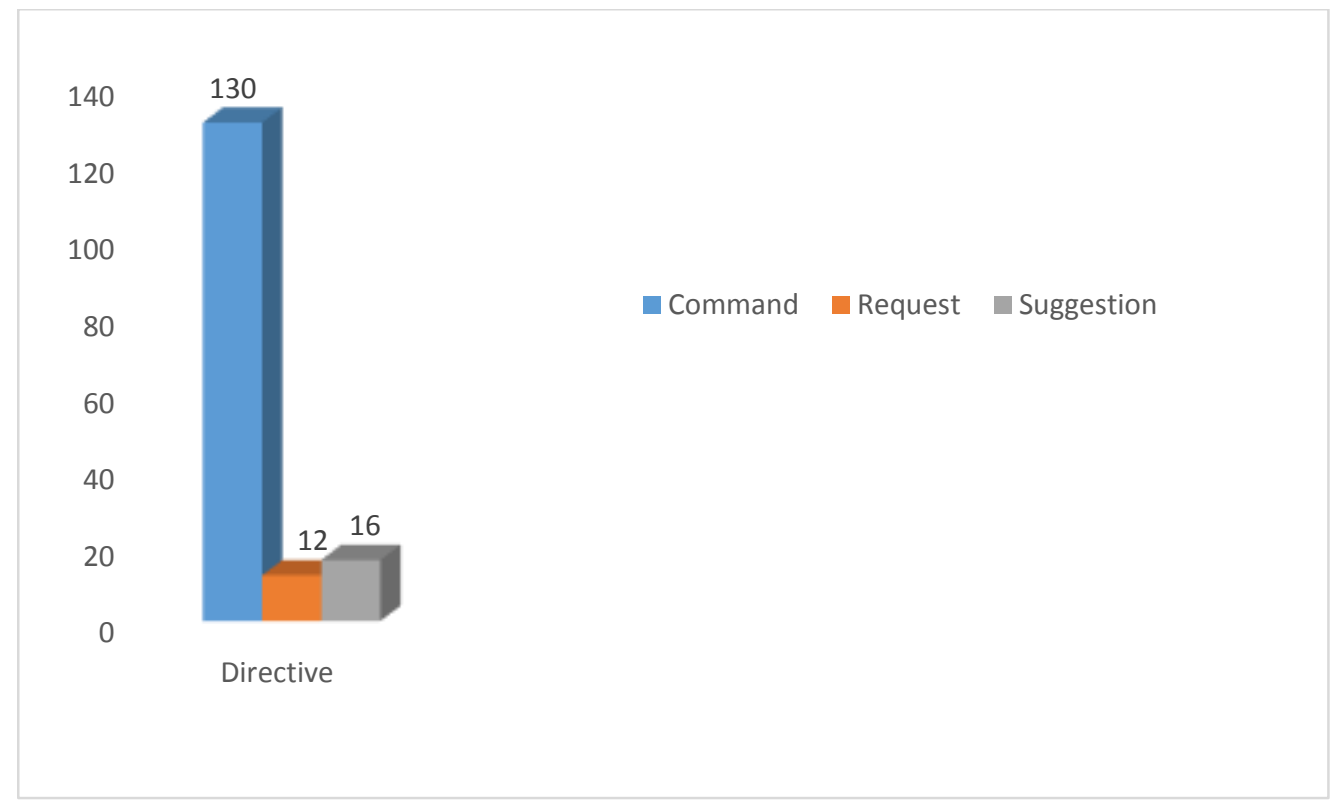

Figure 1. Teacher Directive Production

Based on the figure above, the total production of teacher's directive speech acts in the classroom covers 158 utterances. At the school, teacher produced 130 commands, 12 requests, and 16 suggestions.

\section{a. Command}

A command is a motion made by the speaker to get others to do something they want to do. During the teaching and learning process, a command is used by the teacher to get the students to do something, responding, or acting as the teacher wishes.

In classroom observation, the teacher performs a command in two ways: declarative and imperative forms. For instance:

(1) Code : 032-TD1-A

T : "Yang sudah selesai boleh mengisi tabel di papan tulis."

"Who have finished may fill in the table on the blackboard."

(2) Code : 038-TD1-A

$\mathrm{T} \quad$ : "Okay you read together the sentence, please!"

The first utterance occurs in the main activity when the teacher wants to know students' understanding after she explained the material about present progressive tense. By producing the first utterance, the teacher asks the students to write their answer by filling in the table that have been created by teacher on the blackboard. The second utterance indicates that the teacher is trying to get the students to read the sentence together. It is 
done as only a few students read the sentence aloud while the others are still silent. Thus, the teacher says, "read together" to emphasize her command. Besides, the teacher uses various versions of the directive to show specific communicative functions. The teacher uses declarative form in the first utterance to perform a clear statement of wish or desire to her students in order to fill in the table on the board. Hence, the second utterance shows a command and state politeness by the use of the word please.

\section{b. Request}

A request is an expression of what the speaker desires the hearer to do or to avoid doing. A request does not take full control of the person addressed by the speaker. It means that the speaker may not have the power to express his desire that the hearer act or not act as the speaker wishes.

During the observation, the teacher infrequently produces a request. The researcher found only twelve expressions of request.

In making a request, the modal (can, will, and may) are commonly used. The modal 'can' is used to convey ability, opportunity, a request, to grant permission, to show possibility or impossibility. People are willing to apply can and could to make a request where could sounds softer than can. They regularly use can or could to ask another person to do things politely. A sentence is constructed as a question to present that you are giving it to the addressee to determine whether he wants to share his help or not.

$$
\begin{array}{ll}
\text { Code } & : 008-T D 1-A \\
\text { T } & : \text { "Can you give another example?" } \\
\text { Code } & : 009-T D 1-A \\
\text { T } & : \text { "Can you make the sentence?" }
\end{array}
$$

Furthermore, the modal (can, will, and may) inform the speaker's hoping to get the addressee to do something. In this case, the teacher offers her students to answer one of the students' sheets. The conversation between them is presented in the following.

$$
\begin{array}{ll}
\text { Code } & : 076-\mathrm{TD} 1-\mathrm{A} \\
\mathrm{T} & : \text { "Will be a volunteer or I will appoint you?" } \\
\mathrm{Ss} & : \text { "Volunteer" }
\end{array}
$$

The example above shows the directive act of request. The function form 'will' indicate the auxiliary verb in the future simple tense and can be used to cause a request someone to do something. People generally set up an interrogative form of will to make requests or respectful offers. Besides, utterance number three (3) presents that the teacher attempts to get the student answer about what they have done in their worksheet by giving a solicitation or petition.

\section{c. Suggestion}

A suggestion is an utterance produced by the speaker to other people to accept his opinion as to what the addressee should or should not do. Generally, the speaker expresses an opinion about the addressee's options of performance. However, the utterance assumes that the suggested or individual has a choice of performance. For example:

Code : 029-TD2-A

$\mathrm{T} \quad$ : "If you have any question or you are doubtful about this you can ask $m e^{\prime \prime}$

(2) Code : 135-TD2-A

$\mathrm{T}$ : "If you don't come forward, you don't understand where is the mistake" 
(3)

\author{
Code : 226-TD2-A \\ $\mathrm{T} \quad$ : "If you pay attention, it is not difficult is it? Unless I ask you to read \\ but you are talking with your friends. Because you don't pay attention \\ to me, so you don't connect and it becomes difficult" \\ Code : 240-TD2-A \\ $\mathrm{T} \quad$ : "Okay, this is for exercise and do it at home. If you already \\ understand the material then do the task so that you still remember"
}

There were four expressions of suggestion performed during teaching and learning activities. The examples number $1-4$ above show directive acts of suggestion. The data number (1) indicates that the teacher offers a question-and-answer room for students who have difficulties or problems about understanding the material taught in the classroom. It relates to the teacher's advice and reflects teacher's expressing opinion. Then, the teacher allows students to do her opinion or ignore it.

However, the data number (2) shows teacher's reaction after she advised students to convey their results group discussions and write them down on the whiteboard. The teacher's utterance contains an implicit suggestion that students recognize their mistakes if they choose to obey the teacher's advice.

Furthermore, the data number (3) belongs to the teacher's concern in giving students advice by telling cause and effect illustration to students' difficulties in comprehending the lesson being taught. Here, the teacher emphasizes suggestions explicitly so the students can grasp what the teacher said without ambiguity.

Meanwhile, the data number (4) occurs when the teacher ended the class. The teacher asks the students to do some exercises at home. She suggests that the task should be done as a reinforcement for students to fully comprehend the material that has been learned and points out the idiom of practice makes perfect.

In short, a suggestion is a directive feature in which the teacher, as the directive creator, recommends something to the students. The form of directive generally used by the teacher to offer this kind of meaning is a declarative using the conditional if. Those utterances imply on the student's preferences whether they accepted teacher's opinion or not. Furthermore, the teacher wishes the students to take action in the future. Searle (1969) said that suggestion belongs to directives speech act in which the speaker wants the hearer to perform the future act.

\title{
2. Students' response strategy in responding to teacher's directive utterances
}

Concerning the data gathered from the observation and interview, the researcher found three response strategies made by the students. They are the no-response strategy (silent), asking-for-clarification strategy, and accommodative strategy. The students use those ways to participate in the classroom interaction while the teacher performed some instructions. Here are the students' response strategies, as documented in various classroom contexts.
Context 1 : The teacher introduces a new material that will be learned on that day

Teacher : "The last meeting, we have learned present tense, and now we have new material about the present continuous tense. Okay, let us see a sentence on page 101. Have you found it?"

$$
\begin{array}{ll}
\text { Student A } & : \text { (silent) } \\
\text { Student B } & : \text { (opened the book) Is it, mam? }
\end{array}
$$




\section{Teacher : "Sudah ketemu belum?" \\ Students : "Sudaaahhh"}

The teacher has been producing directive speech acts to her students at the class opening. In English class, the teacher carried out her role by commanding the students to do what she asked. The two students demonstrated individual responses in which student A presented a no-response strategy by taking no overt action. It could happen on the reasons of avoiding difficult questions from the teacher. Lui et al. (2018) stated that a no-response strategy embodies negative statements or may not take active action to separate themselves from unfavorable events by staying silent.

Conversely, student B performed accommodative by showing corrective action of opening the book and asking-for-clarification strategy. Interestingly, the teacher changed her language from English into Indonesian because she noticed that the students had not yet responded; thus, by code-switching the language, the students are supposed to react to her. The teacher's conversation above proves that students will respond to the teacher when she turns her sentence to Indonesian. This finding is in line with the research conducted by Fatma et. al which reports that directive speech acts affect contextual socio-cultural factors within the conversation. It means that the locutors (teacher) sometimes use local language conveying specific meaning to the interlocutors (students) (Fatma et al., 2019). It is similar to Fitria's study that suggests learners should be equipped with the language they can understand and need to have more knowledge in using and delivering some sentences into target language (Fitria, 2012).

Context 2 : The teacher explains about present continuous tense then guides the students to make some examples by observing what happened in the classroom

$\begin{array}{ll}\text { Teacher } & \text { : "Kita buat kalimatnya bagaimana? Am I sitting or standing?" } \\ \text { Students } & : \text { "Standing" } \\ \text { Teacher } & \text { : "Yes, I am standing now." } \\ \text { Teacher } & \text { : "Okay, you see your friends. Are they writing something now?" } \\ \text { Student C } & \text { : (look around the class) "Amrih, mam? Amrih is writing something." } \\ \text { Teacher } & \text { : "That's right. Amrih is writing something on his book." }\end{array}$

Context 3 : The teacher asks one of the students to write the result of what they have discussed to check students' understanding

Teacher : : "Next, number six. You read together!"

Students $\quad:($ read together the sentence $)$

Teacher : "Okay, from that corner." (pointing the students)

"Write your answer there."

Student D : (nod the head then come forward to the class and write down the answer for number six) 
Based on the two different contexts described above, the two students demonstrated the same response strategy, namely accommodative strategy, by making displays and reacting to what happened when the teacher instructed them. In the classroom, the teacher offered contrast instruction in each different context. Additionally, student $\mathrm{C}$ also presented asking for clarification strategy. The student responds to what the teacher asked by returning the teacher's question. It happens to ensure student's comprehension and help him quickly in answering questions by delivering simple expressions. Besides, student D exhibited what she must be done after the teacher pointed her. This result is consistent with the study conducted by Sumilia et. al., which declared nonverbal belongs to students' responses, which are shown by nodded the head when students understood the question or command given by the teacher (Sumilia et al., 2019). Also, some observable responses connected to effective listening and the way of responding include eye contact, head nodding, leaning forward, and having open arms possibly with palms up (Bostrom, 1996; Pease \& Pease, 2004).

To determine the students' reasons for choosing the response strategy, the researcher conducted in-depth interviews. The main issue is how the participants react to teacher's directive utterance. Data is obtained from an interview with the student by posing a question that stresses how well the student understands the teacher's instruction.

I usually understand because the teacher's instructions have been repeated; for example, if the teacher asks PR, I remember the word homework. But, if I do not know the words, I keep silent. I think it is hard because the teacher says full English and I feel confused. (Student A)

\section{I know what the teacher said at whole, if I do not understand, I ask a friend or ask the teacher directly. (Student B)}

Uhmm, for example, if teacher's instruction is not clear, I will ask again. I know what the teacher said and do it, but she uses full English and takes a long time comprehending it. (Student C)

\section{Sometimes I know the teacher's instructions but, I find difficulties when I do not know the meaning. (Student D)}

As depicted in the transcript above, there was information that student A understands the teacher's instructions when he remembers the words. The point is that when the teacher gives repeated words, it became familiar words for the student, so he will be able to respond well. Then, student A also explained that he keeps silent because the teacher says the instruction in full English, and he does not know the meaning of the words so, he cannot grasp the teacher's intention. Hence, he has to translate it into Indonesian; consequently, he prefers to keep silent.

In the contrary, student B showed different performances to respond to the teacher's directives. The student claims that he fully understands the teacher's utterances. It reflects on his activities during the learning English by nodding his head and opening his book as the teacher wishes. The student expresses his interpretation of the teacher's implicit meaning once the teacher asks to see the sentence on page 101. From this case, the student takes the action of opening the book according to teacher's instruction. Besides, the student clarifies that sometimes he finds difficulties comprehending teacher's instruction; then, he usually asks his seatmate and tries to ask the teacher immediately.

Besides, student $C$ admitted that she could interpret teacher's instruction even though she needs some time to grasp what the teacher meant and she will ask for the teacher when the instruction is not clear enough. While student D conceded that she often knows the teacher's ask, she finds difficult meaning that she did not know. 
The responses above show how students comprehend the teacher's instruction, especially in repeated sentences and clear instructions. However, they also mention some challenges they faced, such as not knowing the meaning, lack of vocabulary, and taking some time to absorb the teacher's utterances. Those problems may be a barrier to building effective communication and leading to misunderstanding and confusion. It is parallel to the study (Sumilia et al., 2019), mention that students who have problems responding directly to the teacher's utterances because of some factors; they have difficulty interpreting the teacher's sentences that are ambiguous to them, have trouble with grammar and lack of vocabulary and have a personality type which is shy and fearful of making a mistake. The above factors could affect students in responding to teacher utterances.

\section{CONCLUSION}

Based on the findings and discussion as well as the goal of this research, it can be concluded that generally, the teacher is the subject of attention in the classroom as she plays a crucial role in the school. Successful interaction in which the teacher clearly instructs the students will drive positive learning and run appropriately as scheduled. The teacher produced all kinds of directive speech acts. The first primary type of directive speech acts used by the teacher is a command. Second, teacher directives related to the request. Third, teacher's directives utterances are related to suggestion.

Additionally, there were three students' responses to those three types of directives. They are accommodative, no-response, and asking-for-clarification strategy. Each response strategy is applied to a variety of other reasons that are used by students.

This study contributes to teachers and students by providing critical insight. First, it presents self-assessment for the teacher since her utterances contain some intentions that students may not understand. Then, to discover more about English, classroom language instruction should be commonly used in English. It is suggested that teachers create several indirect speech act variations to demonstrate student comprehension and enhance communication as she is a good figure for students to learn pragmatics. Second, for students, it provides communication outcomes towards communicative competence through being able to interpret the teacher's speech act. Students are able to understand and respond coherent and adequate way to the teacher's utterances so that speech acts failures do not occur and lead to effective communication.

The results of this study suggest a more in-depth investigation related to the issue of this study. Future researchers may analyze teacher-student interactions perceived from other dimensions of speech acts and politeness strategies in learning English. More participants are suggested to collect more different data linked to other utterances.

\section{ACKNOWLEDGMENT}

We are profoundly grateful to all reviewers and editors for accepting our manuscript.

\section{REFERENCES}

Amin, J. N. (2016). Redefining the role of teachers in the digital era. The International Journal of Indian Psychology, 3(3), 40-45.

Andewi, W., \& Waziana, W. (2019). An Analysis of Teacher 's Speech Acts in Teaching and Learning Process. Teknosastik, 17(1), 29-34. 
Azizah, A. N., Suparno, \& Tarjana, S. S. (2019). Speech Acts Used by English Teachers in EFL Classroom. Proceedings of The 3rd Indonesian International Conference on Linguistics, Language Teaching, Literature and Culture, 1(1), 228-235. Retrieved from http://openjournal.unpam.ac.id/index.php/Proceedings/article/view/4332

Azwan, A. (2018). Politeness Strategies of Refusals to Requests by Ambonese Community. Lingua, 15(1), 1-6. https://doi.org/10.30957/lingua.v15i1.426.1.

Basra, S. M., \& Thoyyibah, L. (2017). a Speech Act Analysis of Teacher Talk in an Efl

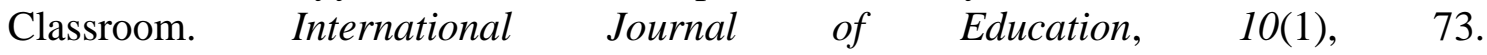
https://doi.org/10.17509/ije.v10i1.6848

Bezemer, J. (2008). Displaying orientation in the classroom: Students' multimodal responses to teacher instructions. Linguistics and Education, 19(2), 166-178. https://doi.org/10.1016/j.linged.2008.05.005

Bijad Alharbi, R. (2018). A Pragmatic Analysis of Pragmatics of Speech Acts in English Language Classrooms at Imam Mohammed Ibn Saud Islamic University. Arab World English Journal, (217), 1-50. https://doi.org/10.24093/awej/th.217

Bostrom, R. N. (1996). Memory, cognitive processing, and the process of "listening" a reply to Thomas and Levine. Human Communication Research, 23(2), 298-305. https://doi.org/10.1111/j.1468-2958.1996.tb00396.x

Brown, H. D. (2001). Teaching by Principles: An Interactive Approach to Language Pedagogy. New York: Longman.

Consolo, D. A. (2006). Classroom oral interaction in foreign language lessons and implications for teacher development. Linguagem \& Ensino, Vol. 9, pp. 33-55.

Creswell, J. W. (2007). Qualitative Inquiry and Research Design: Choosing among Five Approaches (Second edi). Sage Publications, Inc. https://doi.org/10.1111/14679299.00177

Dörnyei, Z., \& Scott, M. L. (1997). Communication Strategies in a Second Language: Definitions and Taxonomies. Language Learning, 47(1), 173-210. https://doi.org/10.1111/0023-8333.51997005

Ezenekwe, U., \& U, K. C. (2019). Skills for 21St Century Teachers Book Chapter (B. Anam, Ed.). Nigeria: Advanced Publishers, Nigeria.

Fatma, F., Prayitno, H. J., Jamaludin, N., Jha, G. K., \& Badri, T. I. (2019). Directive Speech Acts in Academic Discourse: Ethnography of Communication from Gender Perspective in Higher Education. Indonesian Journal on Learning and Advanced Education (IJOLAE), 2(1), 27-46. https://doi.org/10.23917/ijolae.v2i1.8829

Fatma, F., Sumarlam, S., \& Suwandi, S. (2018). Various Language Choice Factors on Local Language Directive Speech Acts at University in Centralof Sulawesi. 262(Ictte), 57-66. https://doi.org/10.2991/ictte-18.2018.10

Fitria, N. A. (2012). The Analyses Of Classroom Speech Acts Produced In The Teaching And Learning Of English As A Foreign Language. Indonesia University of Education.

Haryanto, H., \& Mubarok, H. (2018). Teacher's Directive Expressions Analysis in English Teaching Classes. Lensa: Kajian Kebahasaan, Kesusastraan, Dan Budaya, 8(1), 22. https://doi.org/10.26714/lensa.8.1.2018.22-42

Huang, C.-P. (2010). Exploring Factors Affecting the Use of Oral Communication Strategies. Lunghwa University of Science and Technology, 30, 85-104. Retrieved from https://pdfs.semanticscholar.org/468a/7212e4d3bb4e359f84160c32fe3ef253bfa8.pdf

Hussein, N. O., Albakri, I. S. M. A., \& Seng, G. H. (2019). Pragmatic Competence and Activity-Based Language Teaching: Importance of Teaching Communicative Functions in Iraq EFL Context. International Journal of English Literature and Social Sciences, 4(6), 1655-1660. https://doi.org/10.22161/ijels.46.5 
Hussein, N. O., Albakri, I. S. M. A., \& Seng, G. H. (2020). Developing undergraduate EFL Students' Communicative Competence through Using Pragmatic Instruction. International Journal of English Literature and Social Sciences, 5(1), 232-238. https://doi.org/10.22161/ijels.51.42

Isnawati, F. D., Anam, S., \& Diana, S. (2014). Speech Acts Analysis of the Main Character in Shrek Movie Script (Analisis Tindak Tutur Pada Tokoh Utama Di Dalam Naskah Film Shrek). Publika Budaya, 3(1), 60-64.

Ivana Swastiana, N. M., Putra I.N, A., \& I.W, S. (2020). An Analysis of Speech Acts Used by the Seventh-Grade Teacher of SMPN 2 Bangli in EFL Classroom Interaction. Journal of Education Research and Evaluation, 4(1), 49-58. https://doi.org/10.23887/jere.v4i1.23542

Jabber, K. W., \& Jinquan, Z. (2013). The Modal Verbs: A Speech Act of Request in the Speech of the President of the United States Barak Obama. The Criterion, (12, February 2013), 13.

Kamlasi, I. (2017). The Positive Politeness in Conversations Performed by the Students of English Study Program of Timor University. Metathesis, 1(2).

Kreidler, C. W. (2013). Introducing English semantics, second edition. In Introducing English Semantics, Second Edition. https://doi.org/10.4324/9781315886428

Lado, M. J. (1969). Mastering English Grammar and Idioms. Jakarta: Titik Terang.

Lui, T. W., Bartosiak, M., Piccoli, G., \& Sadhya, V. (2018). Online review response strategy and its effects on competitive performance. Tourism Management, 67, 180-190. https://doi.org/10.1016/j.tourman.2018.01.014

Maskuri, K. D. S., Tarjana, S., Djatmika, D., \& Purnanto, D. (2019). Politeness Strategies in Directive Speech Acts in Local Indonesian Parliament Assembly Proceedings. $\begin{array}{lllll}\text { International Journal of English Linguistics, } & 9(3),\end{array}$ https://doi.org/10.5539/ijel.v9n3p85

Merdana, Seken, K., \& Putra, A. J. (2013). An Analysis of Speech Acts Produced By Elementary School Teachers and Students to Facilitate Teaching and Learning at SDN 10 Pringgasela East Lombok. Jurnal Pendidikan Bahasa Inggris Indonesia, 1. https://doi.org/10.23887/jpbi.v1i0.723

Miles, M. B., Huberman, A. M., \& Saldana, J. (2014). Qualitative Data Analysis Amethods Sourcebook (3rd ed.). Sage Publications, Inc.

Patmo, Y. (2017). an Analysis of Deixis and Speech Act Used in English Teaching and Learning Process. Linguistic, English Education and Art (LEEA) Journal. https://doi.org/10.31539/leea.v1i1.34

Pease, A., \& Pease, B. (2004). The Definitive Book of Body Language. Australia: McPherson's Printing Group.

Prasetyo, R. I., \& Mulyani, M. (2018). "Teacher's Directives Speech Actsin TeachingLearning Interactions:Classroom Discourse Analysis." Seloka, 7(3), 213--221. https://doi.org/https://doi.org/10.15294 /seloka.v7i3.26607

Rasmodjo, V. R. (2016). Grammatical Perspectives of the Teacher-Student Directives as the Instruction to High School Learners in Multilingual Contexts: A Study Case. Proceedings of ISELT FBS Universitas Negeri Padang, 407-411. Retrieved from http://ejournal.unp.ac.id/index.php/selt/article/view/7002

Searle, J. R. (1969). Speech Acts: An Essay in the Philosophy of Language. Cambridge: Cambridge University Press.

Stevanovic, M., \& Kuusisto, A. (2019). Teacher Directives in Children's Musical Instrument Instruction: Activity Context, Student Cooperation, and Institutional Priority. 
Scandinavian Journal of Educational Research, 63(7), 1022-1040. https://doi.org/10.1080/00313831.2018.1476405

Sulistyani, S. (2018). The Power of Directive Speech Acts in EFL Classroom Interaction. 145(Iconelt 2017), 16-20. https://doi.org/10.2991/iconelt-17.2018.4

Sumilia, E., Puspita, H., \& Elfrida. (2019). Students' Responses Toward Teachers' Questions in Senior High School 8 Bengkulu. Journal of Applied Linguistics and Literacy, 3(2), 108-121. https://doi.org/10.1109/MTAS.2004.1371634

Suparno. (2013). Teacher's Directive Utterances in English Classes. Journal of Education and Practice, 4(22), 134-141.

Susanto, A. (2017). An Analysis of Speech Act on English Learning Process at SMP Al-Islam Surakarta in Academic Year 2015/2016. The State Islamic Insitute of Surakarta.

Taguchi, N. (2006). Analysis of appropriateness in a speech act of request in L2 english. Pragmatics, 16(4), 513-533. https://doi.org/10.1075/prag.16.4.05tag

Wensi, F. K., Puspita, H., \& Afriazi, R. (2018). Students' Strategies in Responding Teachers' Oral Questions. Journal of English Education and Teaching, 2(2), 35-45. https://doi.org/10.33369/jeet.2.2.35-45

Wulansari, Y., \& Suhartini, C. (2015). Directive Speech Acts Realization of Indonesian Efl Teacher. English Review: Journal of English Education, 3(2), 1-7. Retrieved from http://journal.uniku.ac.id/index.php/ERJEE

Yule, G. (1996). Pragmatics. Oxford: Oxford University Press.

Zulianti, H. (2018). Speech Acts on Efl Learners' Teaching Performance and Its Implication in Teaching and Learning Activity. SMART, 4(2), 93-106. https://doi.org/10.26638/js.693.203X 